\title{
CHAPTER 15
}

C15 The Collections of the University of Aberdeen, 1495-1807

\author{
Centers and Peripheries, Networks and Culture
}

\section{Peter Davidson and Jane Stevenson}

C15.P1 The early-modern collections of the University of Aberdeen are important to this volume for three principal reasons. First, unusually for a northern European collection, they suffered little disturbance in the sixteenth century because the Reformation in Aberdeen was moderate, with many of the local elite remaining Roman Catholic; thus the collections have an unusual continuity. Second, although in the twenty-first century Aberdeen is a remote regional capital, in the Renaissance economy of sea travel it stood at a frequented crossroads, with constant shipping to Scandinavia, the Baltic, and the Low Countries. These advantages, combined with networks of cosmopolitan Aberdonian expatriates, ensured that the objects, books, and manuscripts in the university collections continually reflected developments in the European world of learning. This sharply contrasts to the insularity of the English Universities of Oxford and Cambridge, which experienced considerable intellectual decline after the Reformation, and reminds us that the Scottish universities, albeit on a modest scale, remained institutions pursuing a program of internationally aware teaching and research. of Aberdeen. Elphinstone had studied at the Universities of Paris and Orleans. He went personally to Rome to convince Pope Alexander VI that the remoteness of northern Scotland from any center of higher learning was creating a serious shortage of lay administrators, doctors of medicine, civil lawyers, and schoolmasters. The pope 
confirmed his supplication in a bull of foundation dated 10 February 1495 , which granted the new university all the privileges of the University of Paris. ${ }^{1}$ Elphinstone was also instrumental in the introduction of printing to Scotland, under his own supervision. According to the Royal Privilege granted on 15 September 1507, this was essentially to print mass-books and breviaries, as well as "Legendis of Scottis Sanctis as is now gadderit and ekit be ane Reverend fader in God, William, Bishop of Abirdene.”2 As this indicates, he initiated a program of historical and liturgical scholarship, of which the principal surviving monuments are the Breviarium Aberdonensis printed by Chepman and Myllar in 1510, and a manuscript martyrology. ${ }^{3}$ Elphinstone summoned Hector Boece (c. 1465-1536) from his position at the University of Paris to be the first Principal of the new University of Aberdeen. ${ }^{4}$ Boece's Paris circle included his fellow historian John Major, the French historian Robert Gaguin,

${ }^{1}$ MS K 1, University Library, Aberdeen. There is a translation of the Bull in F. C. Eeles, King's College Chapel, Aberdeen: Its Fittings, Ornaments, and Ceremonial in the Sixteenth Century (Edinburgh: Oliver \& Boyd, 1956).

${ }^{2}$ Letters patent granted by James IV, 15 Sept. 1507. Quoted in [Cosmo Muir?] ed., Fasti Abirdonenses (Aberdeen: Spalding Club, 1854), xxiiin.

${ }^{3}$ Iain Beavan, Peter Davidson, and Jane Stevenson, "The Breviary of Aberdeen," Proceedings of the Edinburgh Bibliographical Society 6 (2011): 11-41; David Laing, "An Obituary and Calendar of Scottish Saints, Extracted from the Martyrology for the Use of the Church of Aberdeen, a MS. of the Sixteenth Century," Proceedings of the Society of Antiquaries of Scotland 2 (1857): 256-72.

${ }^{4}$ Nicola Royan, "Hector Boece," Oxford Dictionary of National Biography (online). 
translator of Julius Caesar, and Desiderius Erasmus. In 1495, Boece was procurator of the "German nation" - a fictive kin group within the University of Paris to which all Scottish students, among others, were assigned — and Erasmus was a student at Montaigu. Boece sponsored Erasmus's first book, De casa natalitia Jesu (Paris: Antoine Denidel, 1495); he also received a long epistle on poetry from Erasmus and a 1528 list of his works, Index Omnium Lucubrationem. Boece, along with his successor as King's College principal, William Hay, and probably another Scottish humanist called Patrick Panter, attended Erasmus's lectures on the text of the Bible. It was after Boece was called away from Paris to Aberdeen that Erasmus began looking to England for funding. Boece finally arrived in Aberdeen in 1506 and led the university for the following thirty years. The work for which he is now remembered, his fabulous but influential Scotorum Historia, published in Paris in 1527, is not historiography in the modern sense, but a "Livy" for the Scottish peoples, planting their origins in antiquity. It also makes full humanist use of recently rediscovered classical sources: the Annales and Agricola of Tacitus, unearthed by Boccaccio and Poggio in the late fourteenth and early fifteenth centuries, respectively. He himself entertained hopes of making similar discoveries in Iona. ${ }^{5}$ Given the Italians' success in finding long-lost manuscripts in the ancient monastic library of Bobbio, founded by the Irishman Columbanus, the logic that led Boece to search St. Columba's Iona is easily comprehended; and though from our perspective Iona seems a most unlikely harbor for the lost decades of Livy, this was not obvious circa

\footnotetext{
${ }^{5}$ On the evidence of Scotorum Historia VII, 9-10. The view of Boece as no more than a fantasist and romancer has been challenged by Nicola Royan, "Hector Boece and the Question of Veremund," Innes Review 51 (2001): 42 - 62.
} 
1510. Like the investigation of Scottish saints that Elphinstone set in motion, this search for sources is part of a profoundly Renaissance examination of origins and plural antiquities.

The libraries of Boece, Elphinstone, and Boece's successor John Vaus form the nucleus of the Aberdeen collection. Aberdeen is in fact the only ancient British university to retain its founders' library. There has been some attrition over the centuries through neglect, fire, or theft, but at no point, even at the Reformation, has the collection been purged, possibly due to Aberdeen's somewhat tepid uptake of reform. The collection begins with bishop Elphinstone, who gave the institution thirty-four manuscripts and printed books. Many of these are annotated, indicating that they started off as part of his own working library. To the Elphinstone books may be added three manuscripts that belonged to Archibald Whitelaw, a diplomat and bibliophile who was Secretary of State from 1462 to 1493 , one of Scotland's leading humanists, and a personal friend of Elphinstone's who worked closely with him. Whitelaw's gifts, MSS 199, 200, and 257, are late-fifteenth-century commentaries on Gregory IX's Decretals and lectures on the Constitutions of Clement v. These are basic texts for canon law, and it seems fair to deduce that they were given or bequeathed to Elphinstone for the use of his infant Law Faculty.

Boece's gifts to the library were extensive: his personal library was evidently heavy with works of interest to the scholastic philosophers of Paris. He owned Aristotle's Ethics and Politics, which were much studied there in the fifteenth century, and also his Physics, with an extensive commentary by Boece's contemporary, Lambertus de Monte. Boece's historical interests are also reflected in his donations: he gave the Library a copy 
of the so-called Hegesippus, a Latin version of Josephus's account of the Romano-Jewish Wars of the first century AD, and Archibald Whitelaw's compendium of several historical works passed through his hands (now MS 214). Whitelaw perhaps gave the book to Boece, who then bequeathed it to the college; it is a further indication of the close personal relationships that linked the small group of mostly Paris-educated scholars and teachers who were striving to foster humanism in Renaissance Scotland. Two of Boece's books also came down to the second Professor of Medicine, Robert Gray (flourished 1530s/40s), and from thence to the university collection. One particularly interesting bequest, due to the use to which Boece put it as Principal, is a copy of Marsilio Ficino's De Triplici Vita in an edition printed in France about 1494 by Georg Wolf and Johann Philippi de Cruzenach, and finely bound in Paris. ${ }^{6}$ The lodging rooms, placed in the south range, were named for auspicious planets, and it appears that Boece disposed the lodgings of his students following Ficino's suggestions for the best preservation of their health. $^{7}$

Twenty-two of John Vaus's books are still in the library, most of them boldly signed with his distinctive Italic signature, his script itself a witness to the impact of the Italian Renaissance. His books include a variety of works on grammar and aspects of correct Latin style that would have supported his writing on, and teaching of, Latin

${ }^{6}$ William Smith Mitchell, Catalogue of the Incunabula in Aberdeen University Library (Edinburgh: Oliver \& Boyd, 1965), 73-74, no.195 .

${ }^{7}$ This is argued in detail in Peter Davidson and Jane Stevenson, "Ficino in Aberdeen: The Continuing Problem of the Scottish Renaissance," in Journal of the Northern Renaissance 1 (2009): 64-87. 
grammar, but he also owned books showing a leaning towards humanism, such as Dionysius of Halicarnassus's book on Roman antiquities, Aulus Gellius's antiquarian compilation, Attic Nights, and Pliny's Natural History. Another of Boece's successors as Principal, William Hay (flourished 1530s/40s), also made extensive gifts to the library, including a copy of Boece's own History of the Bishops of Aberdeen, which was lost from Aberdeen, and is now in Edinburgh University Library, having come into the hands of Drummond of Hawthornden. The university still has ten of Hay's books. Some books from the cathedral library also survive in the university collections, further witness to the intellectual culture of pre-Reformation Aberdeen. Though the bulk of the cathedral library fell victim to the Reformation, some books were preserved, and eventually came to Marischal College via the Aberdeen Common Library. ${ }^{8}$ This was the town's own collection of books, and its lodgment in the college library points to the fact that both Kings and Marischal functioned as public libraries for the city and surrounding country in the early modern period, and were thus crucial to local networks of knowledge exchange. ${ }^{9}$

Some general points can be made about this early collection. Erasmian humanism came to Scotland as part of the intellectual, and indeed, physical baggage of men such as Hector Boece and Elphinstone. It is surprisingly biased towards printed books, given that when Elphinstone first went to Paris, the first French press was yet to arrive, which

${ }^{8}$ Iain Beavan, Peter Davidson, and Jane Stevenson, The Library and Archive Collections of the University of Aberdeen (Manchester: Manchester University Press, 2011), 11.

${ }^{9}$ Ibid., 12. 
suggests an enthusiastic embrace of the new technology. Most of the printed books were printed in France, and none of them originated in England. All are in Latin. Through the sixteenth and into the seventeenth century this continued to be broadly the case. The earliest substantial acquisition of London-printed books to either college of the university was the bequest of James Fraser (1645-1731), who made his career in London, and was at various times Royal Librarian, a bookdealer, and licenser at Stationers Hall. ${ }^{10}$ The study of early-modern Scots' private book collecting similarly reveals that Scots tended to buy books in Paris, Frankfurt, and Amsterdam rather than in London. This Scottish tendency to look across the channel can be witnessed in John Johnston, who ended his life as a professor of divinity at St. Andrews, and published ten books in his lifetime, none of them in Scotland or England. ${ }^{11}$ We have detailed information about the distribution of one particular book. He asked his friend Robert Boyd of Trochrig, then pastor and professor of philosophy at the Protestant university of Saumur, to have some of his Latin verses printed there. Boyd subsequently noted the transaction cost of $£ 48$ (Scots), and that Thomas Porteau, the printer, gave him half of the edition to dispose of as he chose (360 books). Sixty copies were sent to Scotland "to be given to the authors relations," a hundred went to an unnamed bookseller in Paris, and two hundred to Protestant La Rochelle to be sent on to "H. Laurence," a bookseller in Amsterdam

${ }^{10}$ J. M. Henderson, “James Fraser, 1645-1731,” Aberdeen University Review 25 (193738): $138-46$.

${ }^{11}$ Though five of his works were printed at the expense of the Edinburgh publisher Andrew Hart, and must therefore have been on sale in Edinburgh, they were printed (by various printers) in Leiden. 
(probably Hendrick Laurensz), who would send them on to Frankfurt. None were sent to booksellers in London or Edinburgh. ${ }^{12}$ Almost no books that came to Aberdeen before 1600 are in English, and few of the Latin books that make up the bulk of the collection were printed there. The early library thus points to networks and connections that ran between Aberdeen and centers of intellectual life on the Continent, notably Louvain, Bruges, Antwerp, Orleans, and above all, Paris, quite independent of London, Oxford, and Cambridge.

D. E. R. Watt's monumental prosopography of Scottish graduates before the foundation of St. Andrews tells the same tale: 281 Scots demonstrably took degrees in France, as against 32 in England. ${ }^{13}$ One witness to the Low Countries connections of the university's founders is the epistolary of St. Machar's Cathedral, created in the second quarter of the sixteenth century, and bearing the arms of Bishop Gavin Dunbar, who commissioned it. ${ }^{14}$ It was made in Antwerp, a very humble production of the same school that produced Wolsey's sumptuous epistolary, now at Oxford, Magdalen College, MS Lat. 223. It is the only surviving physical object from the high-altar furniture of preReformation St. Machar's. Another indication of the university's Flemish connection is

${ }^{12}$ Leicester Bradner, Musae Anglicanae: A History of Anglo-Latin Poetry, 1500-1925 (New York: Modern Language Association of America, 1940), 157.

${ }^{13}$ There were also three who took degrees in Germany, and twenty-four in Italy. Data from D. E. R. Watt, A Biographical Dictionary of Scottish Graduates to A.D. 1410 (Oxford: Oxford University Press, 1977).

${ }^{14}$ It is edited by Bruce McEwen, Epistolare in usum Ecclesiae Cathedralis Aberdonensis (Edinburgh: Oliver \& Boyd, 1924). 
bishop Elphinstone's portrait, the only nonroyal portrait to survive from Renaissance Scotland, the work of a Flemish artist, c. 1505, and still owned by the university. Teaching at King's in the first hundred years was oral, and students made their own manuscripts from the teachers' dictation, known as dictata. We have no surviving dictata from fifteenth- or sixteenth-century King's, but there are twenty-six seventeenthcentury collections of students' dictata from King's, and another seven from Marischal. More interesting for the study of networks are dictata from other universities. The law notes of William Elphinstone, Bishop Elphinstone's father, made at Louvain in 1430, can be found in MSS 195-197; and MSS 109-110 are notes on Gisbert de Boscoducis's Lectures on Aristotle made at the University of Louvain by Georgius de Moravia (i.e., of Moray), whose actual surname was Lichton (a note on f. 237v says "this is the book of brother George Lichton, once [the book] of the Abbot of Kinloss"). Lichton matriculated at Louvain in 1467, and thus was probably one of the learned Cistercians of Kinloss, who had many links with the university, and sometimes borrowed books from its library. Imported dictata at Aberdeen are a significant medium for the transmission of knowledge, and a type of manuscript that is particularly revealing about networks. Dictata continued to be important surprisingly late in the library's history. The doctor William Fordyce (1724-92) gave a considerable collection of them to Marischal, where he was briefly rector. He bequeathed just over three hundred printed books to the library, the majority from the seventeenth century, but additionally gave it sixteen dictata. William Knight's "Classified Catalogue of the Most Important Books in the Library of Marischal College" records these: they include " 10 vol $4^{\circ}$ Dictata in 
Aphorismos. H. Boerhaave ... 1734." "15 Hermann Boerhaave (1668-1738) was Professor of Medicine at Leiden and one of the most influential figures in European medicine. These records of his teaching are an important resource for the history and development of medical practice in Britain and beyond. Dr. James Melvin (1795-1853), former Rector of Aberdeen Grammar School, also collected dictata on classical archaeology, which in the mid-nineteenth century was a subject very much in its infancy. Though his own education was entirely at Aberdeen, he took considerable pains to acquire dictata on Greek and Roman antiquities from the pioneering Dutch archaeological scholars of the eighteenth century, who were developing a more scientific approach to archaeological investigation. He bought dictata of the lectures of Petrus Burmann (1668-1741), Christoph Gottlob Saxe (1714-1806), Lambert Bos (1670-1717), Frans van Oudendorp (1696-1761), Sigibert Havercamp (1684-1742), and Lodewijk Caspar Valckenaer (1715-85). There are sixty such manuscript volumes among his collections, which suggests a clear and definite policy. He also seems to have made a point of acquiring, where possible, the books that emerged from these lecture courses: for example, a student's notes from the lectures of Lambert Bos, "Excerpta quaedam ex eius ore in antiquitates Graecas" (notes taken down from his own mouth on Greek antiquities) are supplemented by Bos's published Antiquitatum Graecarum praecipue Atticarum descriptio brevis (Leipzig, 1749). Similarly, he owned notes from Petrus Burmann's lectures on Suetonius along with his edition of the same author. It is interesting that decades-old student notebooks could still be bought when Melvin was collecting (there is no information as to how he sourced them), since it is strongly

\footnotetext{
15 Add MS M 117 and MS 2127/1-10, University Library, Aberdeen.
} 
suggestive of the continued importance of manuscript production as an aspect of the circulation of knowledge in the particular context of university study down to the nineteenth century. Additionally, it is clear that for Melvin, the printed text did not supersede the lecture notes.

The seventeenth century also produces abundant witnesses to Aberdeen's networks and connections. One particularly interesting individual is Duncan Liddel (1561-1613), an Aberdonian who spent most of his life teaching in Continental universities. ${ }^{16}$ He enrolled in the University of Frankfurt an der Oder at the age of eighteen, but may have taken a degree at King's College before that; in the seventeenth century, it was common practice for Scots to take a first degree in Scotland, and a second at a Continental university (very few went to England). In Frankfurt he was taught mathematics, philosophy, and medicine by a fellow Scot, John Craig (1512-1600), a mathematician and astronomer of some distinction, who was an associate of the Danish nobleman Tycho Brahe (1546-1601), one of the most remarkable scientists of the era. On Craig's recommendation, Liddel moved on to Breslau in 1582 to study for a year with a famous astronomer and mathematician, Paul Wittich. Subsequently, Liddel decided to go to Rostock and study philosophy. There he became good friends with the professor of medicine Heinrich Bruceus and the professor of rhetoric Johannes Caselius. Caselius himself left Rostock in 1590 to become Professor of Greek at the new University of Helmstedt, prompting Liddel to follow him there as professor of mathematics a year later.

\footnotetext{
${ }^{16}$ Charles Platts, rev. George Molland, "Duncan Liddel," Oxford Dictionary of National Biography (online).
} 
Liddel taught at Helmstedt for the rest of his career; he is thus connected with its patrons, the Princes of Braunschweig-Wolfenbüttel.

When at Rostock, Liddel made the acquaintance of Brahe, who had himself been a student there in the 1560 s, perhaps through Craig. Liddel visited Brahe at his island observatory of Hven at least twice, in 1587 and 1588. Brahe was generous in giving his books to learned correspondents, and Liddel acquired three. On Recent Phenomena in the Heavenly World (1588) and Astronomical Letters (1596) were published at Uraniborg and presented by the author to suitable recipients. Liddel's copy of another of Brahe's works, Progymnasmata [ $\pi 523$ Bra 1], though it was commercially published in Frankfurt in 1610 , seems also to have been one of the copies privately circulated by Brahe. It is also thanks to the generosity of Brahe that Liddel acquired the Commentariolus of Mikołaj Kopernik, better known as Copernicus (1473-1543), who evolved the revolutionary idea that, contrary to the generally accepted view of the classical astronomer Ptolemy, the earth went around the sun. He resisted publication during his lifetime, and wrote only this brief commentary, a copy of which came into the hands of Brahe. He had the resources at Hven to have copies made, and sent one to Bruceus, a Rostock friend of both men, from whom Liddel (whose interest in Copernicus was intense) was then able to borrow it. Liddel owned both the editio princeps of De Revolutionibus Orbium Coelestium (On the Revolutions of the Heavenly Spheres), published in Nuremberg in 1543, and the second edition of 1566 . He had his copy of the 1566 edition specially bound with interleaved blank pages, and copied into them one of only three surviving manuscripts of the Commentariolus. He also added many of his own notes, and copied some important 
observations by Paul Wittich, creating a fascinatingly complex compendium of the reception of Copernican theory.

Brahe's own response to Copernicus was to suggest a compromise between the two systems. In 1587, he suggested that the sun and moon circled the earth, but all the other planets circled the sun. Liddel's teaching at Helmstedt was fully informed by these recent developments. However, Brahe's great strength as a scientist was as a peerless observer. He was not, in Liddel's view, as strong a mathematician; and so Liddel himself refined and reworked the mathematical demonstrations for the geoheliocentric theory, as it was known. When this news reached Uraniborg, Brahe's affection for Liddel abruptly evaporated. Brahe was always inclined to be jealous of Liddel's work (he similarly fell out with Wittich, to whom he owed a great deal, intellectually speaking). As Brahe saw it, "some insolent little Scot" (insolens iste Scotulus) was presenting geoheliocentrism as his own idea. Liddel wrote to the Danish astronomer to clear his name, pointing out that he had given Brahe full credit for the general form of the geoheliocentric system, but that his students were being taught a revised version, with a more refined mathematical model. Brahe was not mollified.

Though Liddel was associated with some of the most important figures in the world of astronomy, and the closely written margins of his books indicate long and deep thought on astronomical issues, he never published his work in the field. His principal publications were on medicine: Ars Medica, a book on fevers, and a study of melancholia. In 1607, Liddel came to Aberdeen, where he still owned land, but little is known of his activities, except that he set about equipping the newly founded Marischal College to teach the sciences. He left his library, including the books mentioned above, 
and his collection of scientific instruments to Marischal, and also sufficient funds to create a permanent Chair of Mathematics (and Astronomy). This was before either Oxford or Cambridge thought mathematics worthy of a chair. Liddel's donations to Marischal College on his return to Aberdeen thus represent a substantial importation of northern Renaissance culture, medicine, astronomy, and Latin letters into the intellectual life of the university.

The memorial volume for the Episcopalian Bishop of Aberdeen, Patrick Forbes of Corse, printed in 1635 by Edward Raban, printer to the university, is also informative about the Aberdonian Continental diaspora. It includes Latin verse by thirty-nine Scottish poets, most of them connected with Aberdeen University. One was Arthur Johnston of Caskieben, an exceptionally gifted poet, who taught at Heidelberg and Sedan before returning to Aberdeen in $1622 .{ }^{17}$ He was a protégé of Archbishop Laud (itself a witness to the seldom-remembered fact that Laudian Anglicanism was more positively received in the northeast of Scotland than anywhere else in the kingdom).${ }^{18}$ Johnson contributed occasional verses to books such as this tumulus, but his own volumes of verse were published in Sedan, Paris, Middelburg, and Nijmegen. ${ }^{19}$

\footnotetext{
${ }^{17}$ Nicola Royan, “Arthur Johnston,” Oxford Dictionary of National Biography (online).

${ }^{18}$ David Allan, “Alexander Ross,” Oxford Dictionary of National Biography (online).

${ }^{19}$ Propemptikon ad illustrissimum principem Ludovicum Comit. Palatin. Ducem
}

Bavariae, etc. (Sedan: Jean Jannow, 1618); Onopordus furens, autoribus philologis parisiensibus (Paris, 1620); Poemata omnia (Middelburg: Moulert, 1642); Admiranda Rerum Admirabilium encomia (Nijmegen, 1676). 
his career, apart from a year in England, his brother, John Forbes (c. 1565-1634), was banished from Scotland for his opposition to James VI's religious policy in 1605, and became pastor first of the British church in Middelburg, then of the British church in Delft. $^{20}$ Two of his sons became colonels in the Dutch army, one of whom subsequently fought for the Covenanters. Bishop Forbes's son, John Forbes of Corse, studied in Heidelberg and went on to become a preacher in Middelburg before returning to King's College, where he was appointed Professor of Divinity in $1620 .{ }^{21}$ Later in life, he was one of the six "Aberdeen Doctors" who refused to sign the National Covenant and instituted a pamphlet war with its supporters. He was consequently forced to leave Scotland in 1643, and retreated to the Netherlands, where he took up his old connections.

Netherlands, the theological works of Bishop Forbes were published in Middelburg, edited by his son, and the two John Forbeses also published extensively there on their own accounts; John Forbes of Corse also published verse in Heidelberg when he was a student there. ${ }^{22}$ The ramifications of this family, with their multiple connections in the

${ }^{20}$ G. W. Sprott, rev. Alan R. Macdonald, “John Forbes,” Oxford Dictionary of National Biography (online).

${ }^{21}$ David George Mullan, “John Forbes," Oxford Dictionary of National Biography (online).

${ }^{22}$ Epithalamion Et Syncharma Super faustis nuptiis S. Ser[enissim]orum. Friderici V.

Comitis Palatini Rheni ... Et Elisabethae, Potentissimi Jacobi ... Filiae Unicae, Feliciter celebratis Londini XVI. Cal. Martii MDCXIII. Et Laeto eorum 
Netherlands and the Protestant universities of Heidelberg and Sedan, are thus a powerful witness to the internationalism of northeastern Scotland and its connections with a network of learned Protestants. Banishment to a man such as John Forbes was a misadventure but not a disaster: his first port of call on reaching France was to visit an old friend, Robert Boyd of Trochrig, at Saumur. From there, he went to Sedan, where his second cousin and fellow exile, Andrew Melville, had taken refuge. He also spent some time with his brother Arthur, an officer in the Swedish service, before finding a permanent home in Middelburg.

Another aspect of the university's collection that sheds light on its place in international networks is its art collection. The portrait of Elphinstone has already been mentioned; also of interest is a suite of paintings of the Sibyls. These were popular subjects among Protestants, being neither representations of sacred characters, nor aggressively secular. They were commissioned for the Common Hall of Kings College, from George Jamesone (1589/90-1684), the son of a master mason in Aberdeen, in 1635, and head of a dynasty of painters. ${ }^{23}$ While he was highly successful in his own time, some of the colors he used have proved to be impermanent, and all of his surviving work Heidelbergam adventu, Illius quidem III. Idus Maias, Huius vero ... Iun. eodem anno (Heidelberg: Voegelinus, 1613); Genethliaca ... Dn. Friderici V. comitis Palatini Rheni ... et Dn. Elizabethae, potentissimi Iacobi filiae ... primogeniti filij ... nascentis cal. jan. sub horam 12. noctis anno 1614 (Heidelberg: typis J. Lancelloti, 1614).

${ }^{23}$ Duncan Thomson, The Life and Art of George Jamesone (Oxford: Clarendon Press, 1974). 
has been restored to a greater or lesser extent. The Sibyls were repainted in 1761 by his great-grandnephew, Cosmo Alexander. Alexander's father, John Alexander, was also a painter, and had worked in Rome from 1711 to 1715 (this branch of the family were Catholics). Cosmo Alexander, a convinced Jacobite, was declared a wanted man after fighting for the Pretender at the battle of Culloden in 1745. He took refuge in Rome, where he set up a household with two other Scottish Catholics, Patrick Leith, SJ, and George Gray. He began his career as a portrait painter in the city, painting fellow Jacobite exiles, and subsequently moved around the Continent for a number of years, painting Scottish Jacobites wherever he went, thus evidently taking advantage of their networks. He spent some time in London, went to the Netherlands (again, principally painting Scots), and then decided to move to America, where he taught Gilbert Stuart, subsequently famous as the painter of George Washington. Thus, the networking that characterizes Aberdeen scholars is equally evident among those northeasterners who sought the Continent for quite different reasons. Cosmo Alexander was not unique in seeking his fortune in the Americas. One of the earliest Aberdonians to do so was Patrick Copland (c. 1572-1651). Having been educated at Marischal College, after a period as preacher to the navy of the East India Company, he taught in Virginia, where he attempted to found a college at Henrico for the education of the children of Native Americans. After his intentions were disappointed, he became a missionary settler first in Bermuda, then in Eleuthera (the Bahamas), and sent the university a gift of two thousand marks "for the ... Divinitie and Hebrew reader in your schooles." ${ }^{24}$ Later, quite a number of Aberdonians were involved in the settlement

\footnotetext{
${ }^{24}$ MS 991, University Library, Aberdeen.
} 
of Carolina. One of them, a distinguished member of an Aberdeen intellectual dynasty, Dr. Alexander Garden (1730-91), was the first systematic botanist of the American South, and a correspondent of Linnaeus (the gardenia is named for him). Born and educated in Aberdeen, he emigrated to Carolina and practiced medicine in Charleston from 1752 until the Revolution, when, as a Loyalist, he was forced to flee to London. ${ }^{25}$ One of the most significant Aberdonian contributions to the developing intellectual culture of eighteenth-century America is that of Dr. William Smith (17271803), an Episcopalian, educated at King's College, where he matriculated in 1743-44. He emigrated to America in 1751, and his 1753 essay, A General Idea of the College of Mirania, impressed Benjamin Franklin, and led to Smith's appointment to teach logic and natural philosophy at the College of Philadelphia, the nucleus of the University of Pennsylvania. Smith subsequently served as first provost of the college. His continued remembrance of Aberdeen is suggested by the library's copy of the Transactions of the American Philosophical Society, volume 1, printed at Philadelphia in 1771, which is inscribed, "The American Philosophical Society held at Philadelphia humbly desires to cooperate with the University of Aberdeen, in their laudable Endeavours for the Advancement of useful Knowledge," with the further inscription, "Dr Smith begs that Dr Franklin would direct this copy to Dr John Chalmers, Principal, for the library of King's College, Old Aberdeen, in which place Dr Smith had his Education." The nascent American Philosophical Society evidently attracted serious interest in Aberdeen. In the

${ }^{25}$ Margaret Denny, “Linnaeus and His Disciple in Carolina: Alexander Garden,” Isis 38 (1947-48): 161-74. Additionally, MS 2740/10/7, University Library, Aberdeen, contains forty-four letters to and from Dr. Garden. 
papers of the philosopher Thomas Reid, we find the note (June 1769), "Read Experements and Observations in Electricity made at Philadelphia in America by Benjamin Franklin LLD \& FRS."26

With the exception of the Gregory family, an Aberdeen intellectual dynasty with an outstanding record of sustained academic achievement that produced no fewer than sixteen professors between 1600 and 1700, and ramified to Oxford in the person of David Gregory, Savilian Professor of Astronomy, both Aberdeen's collections and the biographies of its professors and students suggest that it was only to a very limited extent part of the circulation and exchange of knowledge within the British Isles. It was, however, profoundly connected with the intellectual life of northern Europe. Almost everyone who taught at the university took at least one degree outside Scotland: the Reformation deflected these men from their traditional destination of Paris, but they went instead to the great Protestant universities, Leiden above all, but also Sedan, Montpellier and Saumur, Heidelberg and Rostock. It is notable that the dictata collected by Fordyce and Melvin both focus on the great savants of the Netherlands. Many of them also taught or preached on the Continent for part of their careers: in its first century, the connections with Paris were strong, and after the Reformation, Scottish Catholics continued to study and teach there, as well as in other French and Italian universities. But throughout the sixteenth, seventeenth, and eighteenth centuries, many men, both Episcopalians and Presbyterians, who had taken their first degrees at King's or Marischal, made their careers on the Continent: men such as Duncan Liddel, mentioned above, or Gilbert Jack, professor of natural philosophy at Herborn and Leiden. Many of them maintained

\footnotetext{
${ }^{26}$ MS 2131/3/1/14, University Library, Aberdeen.
} 
contacts with the university, witnessed by the legacies of books and money that they

made, and when the upheavals of religion or politics forced Aberdonians into Continental exile, they offered a network of associates across the intellectual centers of northern Europe that must have been invaluable. 